\title{
Modulation of $\lambda$ plasmid and phage DNA replication by Escherichia coli SeqA protein
}

Correspondence
Grzegorz Węgrzyn
wegrzyn@biotech.univ.gda.pl

Received 22 December 2006

Accepted 29 January 2007

\author{
Magdalena Narajczyk, ${ }^{1}$ Sylwia Barańska, ${ }^{1}$ Anna Szambowska, ${ }_{1}^{1}$ \\ Monika Glinkowska, ${ }^{1}$ Alicja Węgrzyn ${ }^{2}$ and Grzegorz Węgrzyn ${ }^{1}$ \\ 'Department of Molecular Biology, University of Gdańsk, 80-822 Gdańsk, Poland \\ ${ }^{2}$ Laboratory of Molecular Biology (affiliated with University of Gdańsk), Institute of Biochemistry and \\ Biophysics, Polish Academy of Sciences, 80-822 Gdańsk, Poland
}

\begin{abstract}
SeqA protein, a main negative regulator of the replication initiation of the Escherichia coli chromosome, also has several other functions which are still poorly understood. It was demonstrated previously that in seqA mutants the copy number of another replicon, the $\lambda$ plasmid, is decreased, and that the activity of the $\lambda p_{\mathrm{R}}$ promoter (whose function is required for stimulation of ori $\lambda$ ) is lower than that in the wild-type host. Here, SeqA-mediated regulation of $\lambda$ phage and plasmid replicons was investigated in more detail. No significant influence of SeqA on ori $\lambda$-dependent DNA replication in vitro was observed, indicating that a direct regulation of $\lambda$ DNA replication by this protein is unlikely. On the other hand, density-shift experiments, in which the fate of labelled $\lambda$ DNA was monitored after phage infection of host cells, strongly suggested the early appearance of $\sigma$ replication intermediates and preferential rolling-circle replication of phage DNA in seqA mutants. The directionality of $\lambda$ plasmid replication in such mutants was, however, only slightly affected. The stability of the heritable $\lambda$ replication complex was decreased in the seqA mutant relative to the wild-type host, but a stable fraction of the $\lambda \mathrm{O}$ protein was easily detectable, indicating that such a heritable complex can function in the mutant. To investigate the influence of $\operatorname{seq} A$ gene function on heritable complex- and transcription-dependent $\lambda$ DNA replication, the efficiency of $\lambda$ plasmid replication in amino acid-starved relA seqA mutants was measured. Under these conditions, seqA dysfunction resulted in impairment of $\lambda$ plasmid replication. These results indicate that unlike oriC, SeqA modulates $\lambda$ DNA replication indirectly, most probably by influencing the stability of the $\lambda$ replication complex and the transcriptional activation of ori
\end{abstract}

\section{INTRODUCTION}

Replication of genetic material is a fundamental process that occurs in all living organisms (Kornberg \& Baker, 1992). To ensure survival, this process must be precisely regulated, and this regulation usually occurs at the stage of initiation. In the model prokaryotic organism Escherichia coli, initiation of chromosome replication is controlled in the cell cycle (Messer, 2002). The dnaA gene product is a replication initiator protein. It binds to the oriC region and positively regulates DNA replication initiation. However, in most biological systems, which require precise and versatile regulation to ensure the ability to respond to various growth conditions, there are both positive and negative regulators. The SeqA protein appears to be one of key factors involved in the negative control of oriCinitiated replication ( $\mathrm{Lu}$ et al., 1994; von Freiesleben et al., 1994; Slater et al., 1995; Boye et al., 1996); namely, it is an

Abbreviation: AGE, agarose gel electrophoresis. inhibitor of the onset of chromosome replication in vivo (Slater et al., 1995; Boye et al., 1996).

It has been demonstrated that in vivo SeqA limits DnaA activity in replication from oriC (von Freiesleben et al., 1994). Nevertheless, it has been proposed that the main role of SeqA is sequestration of newly replicated origin sequences, as this protein interacts with hemimethylated GATC motifs, abundant in the oriC region, and prevents DnaA binding to this region ( $\mathrm{Lu}$ et al., 1994; Slater et al., 1995). However, subsequent studies have revealed that SeqA-mediated regulation of replication is significantly more complex. Although SeqA inhibits replication from oriC at high concentrations of DnaA in vitro, it stimulates this process at low DnaA concentrations (Wold et al., 1998). Other experimental lines have indicated that SeqA inhibits open complex formation at the replication origin (Torheim \& Skarstad, 1999).

Studies on DNA supercoiling and the localization of SeqA in cells have suggested that this protein may affect 
organization of the nucleoid (Hiraga et al., 1998; Weitao et al., 1999; Skarstad et al., 2001). In seqA mutants, negative supercoiling of DNA increases, and purified SeqA protein generates positive DNA supercoils in vitro (Klungsoyr \& Skarstad, 2004). Therefore, it has been proposed that binding of SeqA changes either the twist or the writhe of the DNA (Klungsoyr \& Skarstad, 2004). This ability to affect the topology of DNA suggests that SeqA can take part in the organization of the chromosome in vivo. However, it has been proposed that the direct effect of SeqA on replication initiation is rather the result of binding to hemimethylated oriC and releasing DnaA molecules from this region (Taghbalout et al., 2000). Interestingly, several lines of evidence lead to the conclusion that for its proper function, SeqA protein aggregation is required (Lee et al., 2001; Fossum et al., 2003; Han et al., 2003, 2004; Odsbu et al., 2005).

As can be concluded from the data mentioned above, the function of SeqA in replication regulation is definitely not simple. The same applies to the biochemical properties of this protein. Even the rules that govern the binding of SeqA to DNA are not completely clear. Using oligonucleotide templates, it has been demonstrated that SeqA binds specifically to hemimethylated GATC sequences, but not to fully methylated and unmethylated GATC motifs (Brendler \& Austin, 1999; Kang et al., 1999). However, studies of larger DNA fragments indicate that SeqA may interact specifically with fully methylated oriC fragments (Slater et al., 1995; Skarstad et al., 2000). When other (nonoriC) DNA fragments, consisting of several hundred base pairs, are studied, specific binding of SeqA to fully methylated GATC sites is also evident (Słomińska et al., 2001, 2003a, b).

Although the structure of a part of the SeqA protein has been resolved (Guarne et al., 2002), and structure-function studies have been performed (Fujikawa et al., 2003, 2004), some unexpected effects of mutations in the seqA gene have been reported, which strongly suggest that SeqA is involved in the regulation of processes as various as transcription initiation (Słomińska et al., 2001, 2003a; Lobner-Olesen et al., 2003), protein degradation (Torheim et al., 2000; Stomińska et al., 2003c), and biological functions of cellular membranes (Węgrzyn et al., 1999). Moreover, it has been proposed that the function of this protein in the regulation of DNA replication initiation may be linked to E. coli chromosome segregation and cell division (Bach et al., 2003).

Since viruses are intracellular parasites, they use various host proteins for their propagation. Although the use of products of cellular genes by viruses may sometimes appear unusual, studies of such processes have often led to the discovery of important properties of host proteins. This applies also to bacteriophages and their hosts, including one of the most intensively studied models in molecular biology, phage $\lambda$. Examples of the processes described above are the use of E. coli LamB protein, normally allowing uptake of maltose and maltodextrins, for phage adsorption on the cell surface (Vinga et al., 2006), employment of heat-shock proteins in $\lambda$ DNA replication and morphogenesis (Polissi et al., 1995; Taylor \& Węgrzyn, 1995), and involvement of the replication initiator protein DnaA in the regulation of transcription from the $\lambda p_{\mathrm{R}}$ promoter (Szalewska-Pałasz et al., 1998; Glinkowska et al., 2003). Therefore, we aimed to investigate the role of SeqA in the control of replication of the bacteriophage $\lambda$ genome and plasmids derived from this phage. In fact, previous studies have demonstrated that seqA gene function is involved in the regulation of bacteriophage $\lambda$ development, particularly through the facilitation of transcription stimulation from certain promoters, including $p_{\mathrm{R}}$, and that this is crucial for the expression of replication genes and for transcriptional activation of orid (Słomińska et al., 2001, 2003a; Węgrzyn, 2006). Moreover, $\lambda$ plasmid copy number is found to be decreased in seq $A$ mutants relative to wild-type bacteria (Słomińska et al., 2001), and it has been suggested that SeqA interferes with DnaA-mediated regulation of DNA replication initiation from ori (Słomińska et al., 2003b; Glinkowska et al., 2001). On the other hand, the distribution of SeqA-binding sequences (GATC) at oriC and ori is substantially different (GATC motifs are abundant at oriC but not at ori $i$; for reviews, see Messer, 2002; Węgrzyn, 2006). Thus, we assumed that studies of the effects of SeqA on $\lambda$ DNA replication would provide important information, useful to understand in more detail both the functions of this protein and the regulation of bacteriophage $\lambda$ development.

\section{METHODS}

Bacterial strains, phages, plasmids and culture media used in in vivo experiments. Previously described $E$. coli wild-type strain MG1655 (Jensen, 1993) was used. The $\Delta$ seqA $:: \operatorname{Tn} 10$ (called $\Delta$ seq $A$ in this report) and dnaA46 $\Delta$ seqA:: $\operatorname{Tn} 10$ derivatives of this strain were constructed previously by Weggrzyn et al. (1999). The in-frame deletion mutant seqA $\Delta 10$ has already been described (Slater et al., 1995). The MG1655-derived $\Delta$ relA251:: kan $\Delta$ seqA:: Tn 10 strain was constructed by P1 transduction of the $\Delta s e q A:: \operatorname{Tn} 10$ allele from the above-described strain to the $\Delta$ relA251:: kan recipient (Xiao et al., 1991).

Bacteriophage $\lambda$ c I857S7 (Goldberg \& Howe, 1969) was used. The following plasmids derived from this phage were employed: pKB2 (Kur et al., 1987), pCB104 (Boyd \& Sherratt, 1995), pRLM4 (Wold et al., 1982) and pKBlin (Herman-Antosiewicz et al., 1998b). All of them consist of the $\lambda$ replication region and a different antibioticresistance gene.

LB medium (Sambrook et al., 1989) and minimal medium 2 (MM-2) (Węgrzyn \& Taylor, 1992) were used in the in vivo experiments.

Proteins, antibodies and protein fraction. Bacteriophage $\lambda \mathrm{O}$ and $\mathrm{P}$ proteins were prepared from E. coli strain MM294 (Tabor \& Richardson, 1985) bearing plasmids pGP1-2 and pEW1. The latter plasmid was constructed by replacement of the EcoRI-SstII fragment from pIK12 (Konieczny \& Marszałek, 1995) with an analogous fragment of pKB2 (Kur et al., 1987). Thus, overexpression of the $O$ and $P$ genes was possible in the T7 RNA polymerase/promoter system (Tabor \& Richardson, 1985). $\lambda \mathrm{O}$ and $\mathrm{P}$ proteins were purified as 
described previously (Żylicz et al., 1984). SeqA protein, purified according to a published method (Skarstad et al., 2000), was a kind gift from Dr Kirsten Skarstad, Institute of Cancer Research, Oslo, Norway, as were anti-SeqA antibodies.

Fraction II, an extract containing proteins necessary for DNA replication, was prepared according to an already-published procedure (Fuller et al., 1981). E. coli C600 strain (Appleyard, 1954) was grown in $\mathrm{LB}$ medium at $37^{\circ} \mathrm{C}$ to $\mathrm{OD}_{600}=1.0$. The cells were collected by centrifugation, washed in buffer A ( $25 \mathrm{mM}$ HEPES/KOH, pH 7.6, $5 \mathrm{mM}$ EDTA) and then resuspended thoroughly in the same buffer ( $2 \mathrm{ml}$ buffer A per $1 \mathrm{ml}$ cell paste). The cell paste was transferred to a polypropylene tube, quickly frozen in liquid nitrogen and stored at $-70{ }^{\circ} \mathrm{C}$. The frozen cell suspension was thawed at $0-4{ }^{\circ} \mathrm{C}$, and $\mathrm{KCl}$, lysozyme and DTT were added to final concentrations of $150 \mathrm{mM}$, $0.5 \mathrm{mg} \mathrm{ml}^{-1}$ and $2 \mathrm{mM}$, respectively. Following incubation at $0{ }^{\circ} \mathrm{C}$ for $30 \mathrm{~min}$, the cells were frozen again in liquid nitrogen, thawed at $0-4{ }^{\circ} \mathrm{C}$ and centrifuged in a Beckman 50.2 Ti rotor at 30000 r.p.m. for $30 \mathrm{~min}$ at $4{ }^{\circ} \mathrm{C}$. The supernatant was collected and ammonium sulfate $(0.28 \mathrm{~g}$ per $\mathrm{ml}$ cleared lysate) was slowly added to the lysate with stirring over a $60 \mathrm{~min}$ period at $0{ }^{\circ} \mathrm{C}$. The precipitate was collected by centrifugation at 23000 r.p.m. for $20 \mathrm{~min}$ at $4{ }^{\circ} \mathrm{C}$ and packed into a dialysis tube. The pellet was resuspended in $100 \mu \mathrm{l}$ buffer B (25 mM HEPES/KOH, pH 8.0, 0.1 mM EDTA, 2 mM DTT) and dialyzed against $200 \mathrm{ml}$ buffer $\mathrm{B}$ at $0{ }^{\circ} \mathrm{C}$ for $30 \mathrm{~min}$. The fraction extract was frozen in aliquots in liquid nitrogen and stored at $-70{ }^{\circ} \mathrm{C}$.

In vitro DNA replication. The standard reaction mixture (final volume $25 \mu \mathrm{l}$ ) consisted of: $40 \mathrm{mM}$ HEPES/KOH, $\mathrm{pH} 7.6,11 \mathrm{mM}$ magnesium acetate, $50 \mu \mathrm{g} \mathrm{BSA} \mathrm{ml}{ }^{-1}, 40 \mathrm{mM}$ creatine phosphate, $20 \mu \mathrm{g}$ creatine kinase $\mathrm{ml}^{-1}, 2 \mathrm{mM}$ ATP, $0.5 \mathrm{mM}$ GTP, $0.5 \mathrm{mM}$ CTP, $0.5 \mathrm{mM}$ UTP, $0.1 \mathrm{mM}$ dATP, $0.1 \mathrm{mM}$ dGTP, $0.1 \mathrm{mM}$ dCTP, $0.1 \mathrm{mM}$ dTTP with $\left[{ }^{3} \mathrm{H}\right] \mathrm{dTTP}$ (150 c.p.m. pmol ${ }^{-1}$ ), $8.6 \mu \mathrm{g}$ PEG $6000 \mathrm{ml}^{-1}$, 250 ng supercoiled pRLM4 plasmid DNA [purified by ultracentrifugation in a cesium chloride/ethidium bromide gradient, as described elsewhere (Sambrook et al., 1989)], $300 \mathrm{ng} \lambda$ O protein and $80 \mathrm{ng} \lambda \mathrm{P}$ protein. SeqA protein was either absent or added to the concentrations indicated. The mixtures were assembled in an ice bath. The reactions were started by the addition of $1.5 \mu$ fraction II and then the samples were incubated at $32{ }^{\circ} \mathrm{C}$ for $2 \mathrm{~h}$. In some experiments, $1.5 \mu \mathrm{l}$ undiluted anti-SeqA serum was added to fraction II and incubated for $12 \mathrm{~min}$ in an ice bath before mixing with other components. Total ${ }^{3} \mathrm{H}$-labelled nucleotide incorporation was measured by determining the radioactivity (in a scintillation counter) of samples after TCA precipitation and filter binding.

Density-shift experiments. Density-shift experiments were performed according to a previously published method (Węgrzyn et al., 1995b). Briefly, bacteria were grown in a 'light' MM-2 overnight at $37^{\circ} \mathrm{C}$, and after dilution $(1: 50, \mathrm{v} / \mathrm{v})$ with fresh medium the cultivation was prolonged to $\mathrm{OD}_{500}=0.2$. The bacteria were sedimented, washed with TM buffer (10 mM Tris/ $\left.\mathrm{HCl}, \mathrm{pH} 7.2,10 \mathrm{mM} \mathrm{MgSO}_{4}\right)$ and suspended with 0.1 volume of this buffer. After $60 \mathrm{~min}$ incubation at $37{ }^{\circ} \mathrm{C}$, the $\left[{ }^{3} \mathrm{H}\right]$ thymidine-labelled phage $\left(9 \times 10^{-5}\right.$ c.p.m. p.f.u. ${ }^{-1}$ ) was added to m.o.i. $=10$ and incubation was continued for $15 \mathrm{~min}$. The suspension was sedimented, resuspended in the original volume of prewarmed (to $37{ }^{\circ} \mathrm{C}$ ) 'heavy' minimal medium (containing $\left[{ }^{15} \mathrm{~N}\right] \mathrm{NH}_{4} \mathrm{Cl}$ and $\left[{ }^{13} \mathrm{C}\right]$ glucose instead of $\mathrm{NH}_{4} \mathrm{Cl}$ and glucose, respectively), and further incubation was performed at $37{ }^{\circ} \mathrm{C}$. Samples of the infected culture were withdrawn at the indicated times, and total DNA was isolated and ultracentrifuged in the $\mathrm{CsCl}$ density gradient, as described previously (Węgrzyn et al., 1995b). Fractions were collected from the bottom of the tube and the radioactivity of each fraction was measured in a scintillation counter.

2D-agarose gel electrophoresis (AGE). Analysis of $\lambda$ plasmid replication intermediates by $2 \mathrm{D}$-AGE was performed according to a method described elsewhere (Viguera et al., 1996), with modifications described subsequently (Śrutkowska et al., 1999). Before electrophoresis, plasmid pCB104 was digested with EcoRI, EcoRV or SspI/PvuI.

Electron microscopy. Electron microscopy analysis of replicating plasmid DNA molecules was performed as described previously (Burkardt \& Lurz, 1984; Śrutkowska et al., 1998).

Estimation of $\mathbf{O}$ protein stability. The stability of the $\lambda \mathrm{O}$ protein in E. coli cells was investigated, as described previously (Węgrzyn et al., 1995a), by $\left[{ }^{35}\right.$ S]methionine labelling of bacteria growing in MM-2 medium for $20 \mathrm{~min}$, followed by chasing with an excess of unlabelled L-methionine $\left(1 \mathrm{mg} \mathrm{ml}^{-1}\right)$, cell lysis, immunoprecipitation with anti$\lambda$ O serum, SDS-PAGE, autoradiography and densitometry.

Plasmid DNA replication in amino acid-starved bacteria. Bacteria were grown in MM-2 medium, and isoleucine starvation was induced by addition of $\mathrm{L}$-valine to a final concentration of $1 \mathrm{mg}$ $\mathrm{ml}^{-1}$. Samples of bacterial cultures were withdrawn at indicated times, plasmids were isolated from cells by alkaline lysis, and the amount of plasmid DNA was estimated after AGE and densitometric analysis of plasmid bands on an electrophoregram, as described previously (Herman-Antosiewicz et al., 1998b).

\section{RESULTS}

\section{In vitro $\lambda$ DNA replication in the presence and absence of SeqA}

The SeqA protein regulates replication initiation from oriC directly, as demonstrated in studies of the in vitro replication of E. coli minichromosomes (Slater et al., 1995; Wold et al., 1998; Torheim \& Skarstad, 1999). Since a decreased copy number of plasmids derived from bacteriophage $\lambda$ in seqA mutants has been reported previously (Stomińska et al., 2001), we asked whether the influence of SeqA on replication of these replicons was direct or indirect. Note that the only specific effect of SeqA reported to date that could influence $\lambda$ DNA replication was the regulation of $p_{\mathrm{R}}$ promoter activity (Słomińska et al., 2001).

In vitro replication experiments were performed using a $\lambda$ plasmid supercoiled DNA template, purified $\lambda \mathrm{O}$ and $\mathrm{P}$ proteins, and a fraction of replication proteins (called fraction II). In such an experimental system, transcription from $p_{\mathrm{R}}$ is effective due to the presence of RNA polymerase in fraction II (Wold et al., 1982; for a review, see Taylor \& Węgrzyn, 1995). In our experiments we used $\lambda$ plasmid DNA template isolated from wild-type E. coli cells growing exponentially under standard laboratory conditions. DNA isolated from such bacteria should theoretically be a mixture of hemimethylated and fully methylated molecules. However, assuming that replication of a $\lambda$ plasmid molecule takes less than $1 \mathrm{~min}$, and considering the kinetics of DNA methylation, it appeared that fully methylated plasmid DNA was predominant in the preparations. On the other hand, it has previously been demonstrated that both the in vivo and in vitro effects of the $\Delta$ seqA mutation and SeqA protein on $\lambda$ plasmid copy number and $p_{R}$ activity, as well as the binding of SeqA to the $\lambda$ DNA 
replication region, are of equal efficiency and of the same specificity with respect to both hemimethylated and fully methylated DNA (Słomińska et al., 2001, 2003b).

We observed no significant effects of SeqA on in vitro replication initiated from ori $\lambda$. First, because our Westernblotting analysis revealed that fraction II contains some SeqA protein (data not shown), we tested the effects of neutralization of this protein by anti-SeqA antibodies on $\lambda$ DNA replication. No significant differences were observed in the efficiency of $\lambda$ DNA synthesis in the presence and absence of anti-SeqA serum (synthesis in the presence of the serum was $86 \pm 6 \%$ of that measured in the absence of anti-SeqA antibodies). Second, in contrast to previous in vivo studies (Słomińska et al., 2001), the in vitro results presented in this report indicated a slight inhibition rather than stimulation of $\lambda$ DNA replication by SeqA. Similar results were obtained irrespective of whether SeqA was pre-incubated with DNA template or added together with other replication proteins (Fig. 1). These results show that a direct influence of SeqA on $\lambda$ DNA replication is unlikely.

\section{Bacteriophage $\lambda$ replication in infected $E$. coli seqA mutant}

There are two modes of phage DNA replication after infection of the $E$. coli host by $\lambda$ (Węgrzyn \& Węgrzyn, 2002, 2005). Early after infection, phage DNA replicates according to the circle-to-circle $(\theta)$ mode, which is switched later on to the rolling-circle $(\sigma)$ mode. Since only a few of many (50-100 on average) copies of a circular $\lambda$ genome that appears after several rounds of $\theta$ replication switch to $\sigma$ replication, the chance is small that parental DNA strands of a DNA molecule that was injected from a phage capsid into the host cell enter rolling-circle replication (Węgrzyn \& Węgrzyn, 2002, 2005). This has

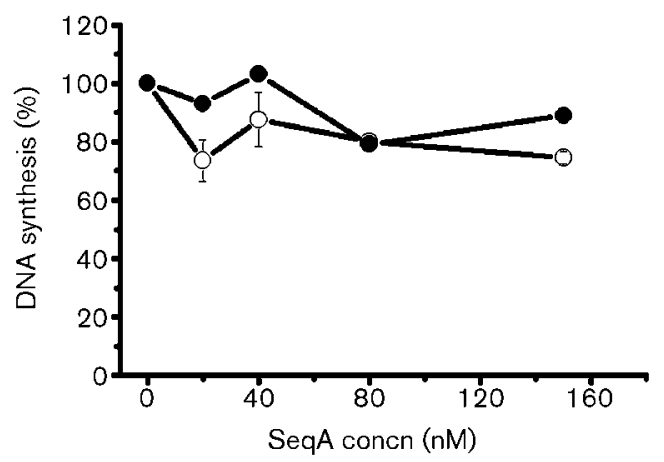

Fig. 1. In vitro replication of $\lambda$ plasmid (pRLM4) in the presence of various amounts of the SeqA protein. SeqA was added to the reaction mixture simultaneously with other proteins (0) or incubated with DNA template for $15 \mathrm{~min}$ prior to addition of fraction II $(\bigcirc)$. The amount of $\lambda$ DNA synthesized in the absence of SeqA was taken as $100 \%$ and corresponds to 75 pmol. been employed in density-shift experiments to monitor the modes of $\lambda$ DNA replication and detect the early appearance of the $\sigma$ replication intermediates (Węgrzyn et al., 1995; Barańska et al., 2001). If wild-type host cells are infected with $\lambda$ virions bearing radioactively labelled DNA, and further cultivation is performed in a heavy but nonradioactive medium (a medium containing heavy isotopes of $\mathrm{C}$ and $\mathrm{N}$ ), followed by cell lysis and ultracentrifugation in a $\mathrm{CsCl}$ density gradient, the radioactivity can only be observed in the fully light and heavy-light fractions. On the other hand, in mutants causing an earlier switch from $\theta$ to $\sigma$ replication and/or predominant rolling-circle replication, parental $\lambda$ DNA strands are likely to be a part of $\sigma$ intermediates and the radioactivity moves toward the fully heavy position (Fig. 2a).

In this type of experiment, 60 min after phage infection of the wild-type cells, we could observe parental $\lambda$ DNAspecific radioactivity only at positions fully light (DNA molecules that did not enter replication) and heavy-light (parental DNA molecules after one or more rounds of $\theta$ replication). However, in the $\lambda$-infected seqA mutant, a part of the radioactivity derived from parental $\lambda$ DNA moved toward the fully heavy position (Fig. 2b). These results suggested that in the seqA mutant the rolling-circle replication starts earlier and is more abundant than in wild-type bacteria.

\section{Directionality of $\lambda$ DNA replication in the seqA mutant}

It has been proposed previously that initiation of the $\sigma$ mode of bacteriophage $\lambda$ DNA replication is preceded by one round of unidirectional $\theta$ replication (in contrast to bidirectional replication, which predominates at early stages of phage development) (Barańska et al., 2001). Therefore, to determine whether the SeqA-mediated delay in the $\theta$ to $\sigma$ switch results from a SeqA-driven stimulation of bidirectional replication, we investigated the directionality of $\lambda$ plasmid replication in wild-type cells and seqA mutants. One should note that $\lambda$ plasmid copy number is decreased in seqA mutants (Słomińska et al., 2001) and that plasmids form multimers. Nevertheless, we assumed that these facts did not influence the interpretation of the results significantly.

Analysis of the results of 2D-AGE experiments indicated that there were few differences in the directionality of $\lambda$ plasmid replication between wild-type and $\Delta s e q A$ strains (Fig. 3a, b). Interestingly, the seq $A$ mutation partially suppressed the effects of $d n a A$ gene dysfunction on $\lambda$ DNA replication directionality demonstrated previously (Barańska et al., 2001). In contrast to the dnaA46 single mutant, in which a high predominance of unidirectional replication has been reported (Barańska et al., 2001), in the double mutant dnaA46 $\Delta$ seqA, both unidirectional and bidirectional replication intermediates could be clearly visualized (data not shown). The suppression was however partial, as in contrast to the wild-type host, in which 
(a)
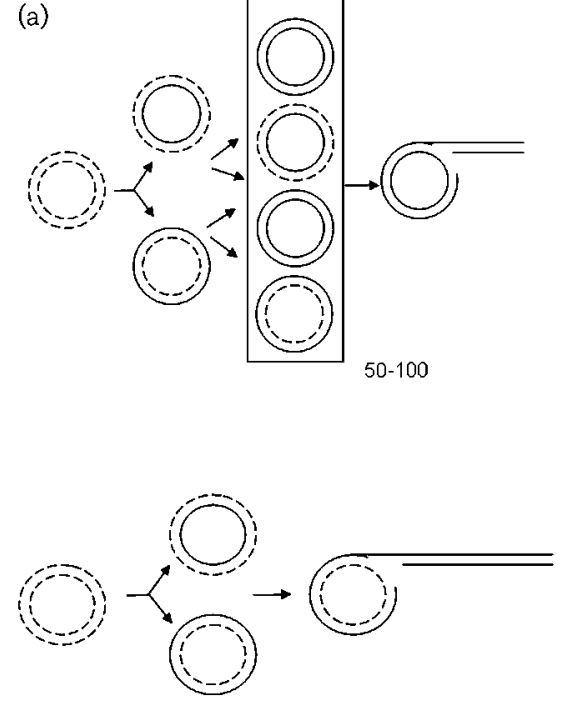

(b)
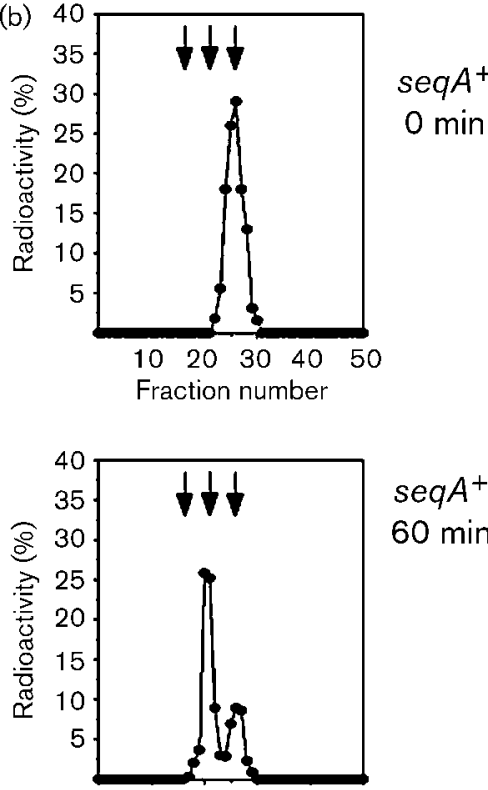

$10 \quad 20 \quad 30 \quad 40 \quad 50$

Fraction number

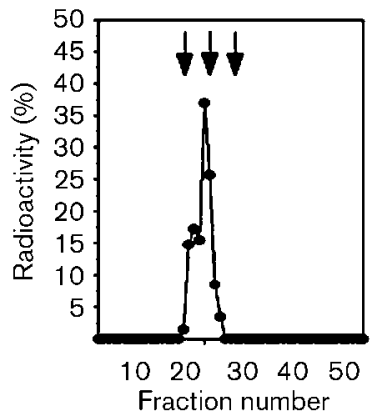

$\operatorname{seq} A^{+}$

$60 \mathrm{~min}$
$\Delta s e q A$

$60 \mathrm{~min}$

Fig. 2. Fate of DNA of infecting $\lambda$ phage in $E$. coli seq $A^{+}$and $\Delta$ seqA hosts. (a) Diagram of experiments and possible results. Radioactively labelled parental phage DNA (dashed-line circles) starts its replication in bacteria growing in the heavy, nonradioactive medium. After the first round of replication, two molecules of $\lambda$ DNA appear, each consisting of one radioactive light strand (dashed circles) and one non-radioactive heavy strand (solid circles). Next, several rounds of $\theta$ replication result in the formation of many (50-100 on average) $\lambda$ DNA molecules, but only two of them can contain a radioactive strand, and thus radioactivity can be detected only at the heavy-light position after DNA isolation and ultracentrifugation on a $\mathrm{CsCl}$ density gradient. Since only a few of these 50-100 $\lambda$ DNA molecules enter $\sigma$ replication at late stages of phage development, there is a very low probability that any of these rolling-circle molecules would contain a radioactive strand, and as such they are not detected in these experiments [(a), upper panel]. The lower panel of (a) shows a situation in which $\sigma$ replication starts early after infection or rolling-circle molecules are highly predominant in the population of $\lambda$ DNA molecules. Such replication intermediates are likely to contain a light, radioactive parental DNA strand and a newly synthesized, heavy, non-radioactive tail, which leads to the transfer of the radioactivity toward the fully heavy position during density-gradient ultracentrifugation. (b) Experimental results. E. coli seqA $A^{+}$and $\Delta s e q A$ strains growing in the minimal light medium (at $30^{\circ} \mathrm{C}$ ) were infected with phage $\lambda c / 857 S 7$ (m.o.i.=10) labelled with $\left[{ }^{3} \mathrm{H}\right]$ thymidine $\left(9 \times 10^{-5}\right.$ c.p.m. p.f.u. $\left.{ }^{-1}\right)$, and further incubation was perfomed in heavy medium

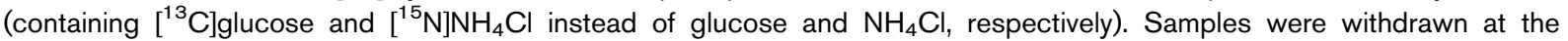
indicated times, and total DNA was isolated and centrifuged in a $\mathrm{CsCl}$ density gradient. Five-drop fractions were collected from the bottom of the tube, and the radioactivity in each fraction was estimated in a scintillation counter. Arrows indicate the positions of fully heavy, heavy-light and fully light DNA (from left to right in each sub-panel). The results of the experiment with the $\operatorname{seq} A$ mutant at time 0 were analogous to those obtained for the wild-type host (i.e. only a single peak at the fully light position was detected; data not shown). The experiments were repeated three times with roughly the same distribution of the peaks. 
(a)
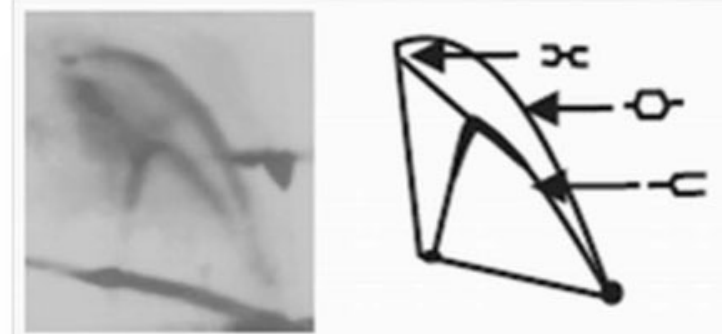

(b)

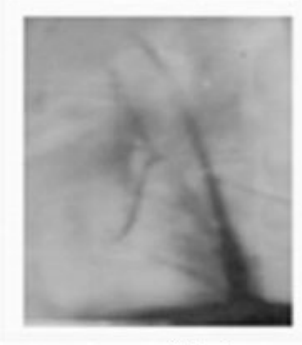

Uni-L

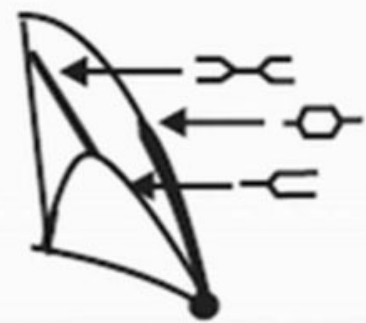

Uni-R

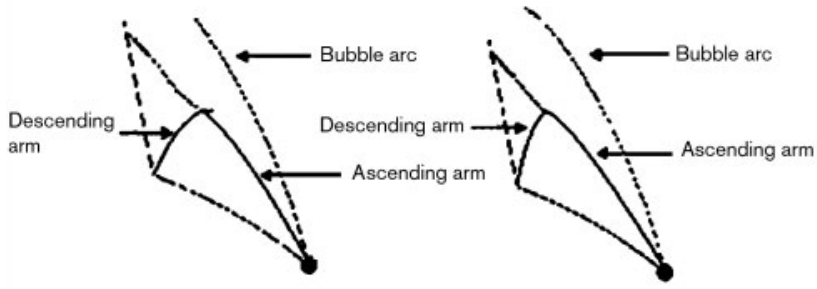

$\mathrm{Bi}$

All

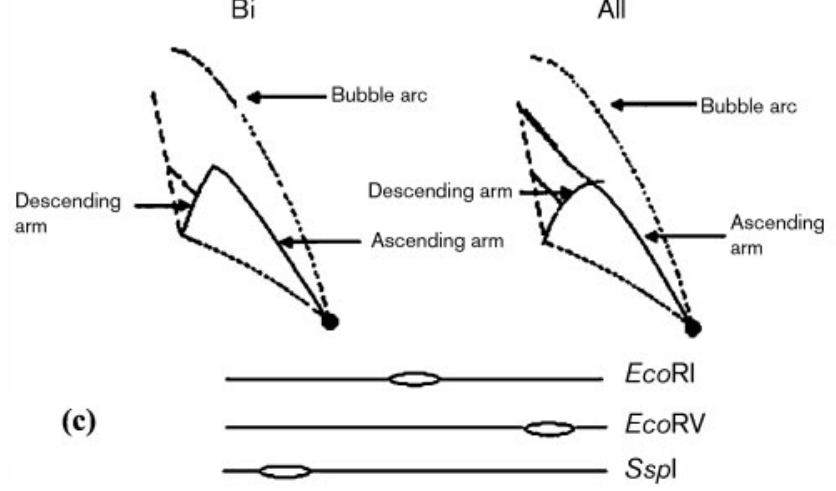

roughly equal frequencies of unidirectional and bidirectional replication could be deduced (Fig. 3a), in the dnaA46 $\Delta$ seqA cells the accumulation of simple-Y and late double-Y structures, as well as short bubble arcs, suggested a somewhat more frequent unidirectional (preferentially leftward) replication than a bidirectional one (data not shown).

The results obtained in 2D-AGE experiments were generally confirmed in electron microscopic studies. $\lambda$ plasmids were isolated from bacterial cells and linearized with restriction enzymes, and molecules with replication intermediates were analysed under the electron microscope. We found little influence of the seqA mutation on the directionality of $\lambda$ plasmid replication (roughly $50 \%$ of bidirectional and unidirectional replication in both $s e q A^{+}$
Fig. 3. $2 D-A G E$ of the $\lambda$ plasmid (pCB104). The results obtained after isolation of plasmid DNA from cultures of $E$. coli seqA $A^{+}$(a) and $\triangle$ seq $A$ (b) hosts bearing pCB104 and growing at $30{ }^{\circ} \mathrm{C}$ are presented in the left-hand panels. Plasmid DNA was digested with EcoRI before electrophoresis. Schemes of the electrophoretic profiles are shown in the corresponding right-hand panels. Theoretical schemes based on the electrophoretic profiles of replication according to the unidirectional leftward $\theta$ mode (Uni-L), the unidirectional rightward $\theta$ mode (Uni-R), the bidirectional $\theta$ mode $(\mathrm{Bi})$ and a combination of molecules replicating according to all these modes (All) are shown below. The schemes were obtained using a computer model for the analysis of DNA replication intermediates by 2D-AGE (Viguera et al., 1998). Consistent data were obtained after digestion of pCB104 with EcoRV or Sspl and Pvul (data not shown). (c) Schemes of pCB104 digested with particular enzymes, with ori marked as a bubble. The theoretical patterns of electrophoretic profiles in the case of bidirectional and unidirectional replication of pCB104 were predicted based on the assumption that replication forks initiate synchronously at ori $i$ and travel at the same rate in each direction.

and $\Delta$ seq $A$ hosts), and a partial suppression of the effect of dnaA46 mutation by the $\Delta s e q A$ allele (roughly $10 \%$ of bidirectional and $90 \%$ of unidirectional replication in the dnaA46 mutant, and $30 \%$ of bidirectional and $70 \%$ of unidirectional replication in the $\operatorname{dnaA46} \Delta s e q A$ double mutant; data not shown).

\section{Effect of seqA mutation on stability of the $\lambda$ heritable replication complex}

It has been demonstrated previously that after initiation of a new round of $\lambda$ DNA replication, the once-formed replication complex is not disassembled but rather inherited by one of two daughter DNA copies (Węgrzyn et al., 1992, 1996a; Wegrzyn \& Taylor, 1992). Interestingly, subsequently, a similar phenomenon has been proposed to occur in eukaryotic cells also (Duncker et al., 2002; Li \& DePamphilis, 2002). In $\lambda$, the heritable replication complex consists of $\lambda \mathrm{O}$ and $\mathrm{P}$ proteins and at least two hostencoded proteins, DnaB and DnaK (Potrykus et al., 2002), and occurs in both bacteriophage $\lambda$-infected cells and those bearing $\lambda$ plasmids (Węgrzyn et al., 1995a, 1996a). The existence of the heritable $\lambda$ replication complex can be monitored by measurement of the stability of the $\lambda \mathrm{O}$ protein, which is rapidly degraded in a free form in E. coli cells but is protected from proteolysis by other components of the complex (Węgrzyn et al., 1992, 1995a, 1996b, 1998).

To monitor the stability of the $\lambda \mathrm{O}$ protein in $\lambda$ plasmid-bearing wild-type and seqA strains, the cells were pulse-labelled with radioactive methionine, and following chasing with an excess of unlabelled methionine, samples of bacterial culture were withdrawn and analysed. After cell lysis, immunoprecipitation with anti-O serum, and SDSPAGE, the radioactivity of protein bands was estimated. We found that a stable fraction of the $\lambda \mathrm{O}$ protein, 
corresponding to the heritable replication complex, existed in both wild-type and seqA mutant hosts. However, this fraction was less abundant in the mutant (Fig. 4), suggesting that SeqA is required for fully pronounced stabilization of the $\lambda$ replication complex.

It has been demonstrated that the $\Delta \operatorname{seq} A(\Delta \operatorname{seq} A:: \operatorname{Tn} 10)$ mutation also results in impairment of expression of the cistronic gene pgm (Lu et al., 1994). Recently, Hardy \& Cozzarelli (2005) have found that deletion of pgm affects chromosome topology, without affecting plasmid supercoiling. Nevertheless, since changes in DNA topology can affect the stability of the ori $\lambda$-bound replication complex (Węgrzyn et al., 1998), we repeated the experiments described above using the seqA $\Delta 10$ mutant, in which the in-frame deletion does not influence expression of pgm. The results of experiments with this mutant were analoguous to those obtained using $\Delta \operatorname{seq} A:: \operatorname{Tn} 10$ (data not shown), indicating that dysfunction of pgm has no significant influence on the investigated processes.

\section{Replication of $\lambda$ plasmids in the seqA mutant during the relaxed response}

During amino acid starvation, when new replication complexes cannot be formed due to inhibition of protein synthesis, replication of $\lambda$ plasmids may occur solely due to the activity of the heritable replication complex (Węgrzyn \& Taylor, 1992). However, transcriptional activation of oril (transcription initiated at the $p_{\mathrm{R}}$ promoter and passing through the origin region) is necessary for initiation of $\lambda$ plasmid replication in vivo. Thus, synthesis of $\lambda$ DNA is inhibited in amino acid-starved wild-type cells, due to guanosine tetraphosphate (ppGpp)-mediated impairment of

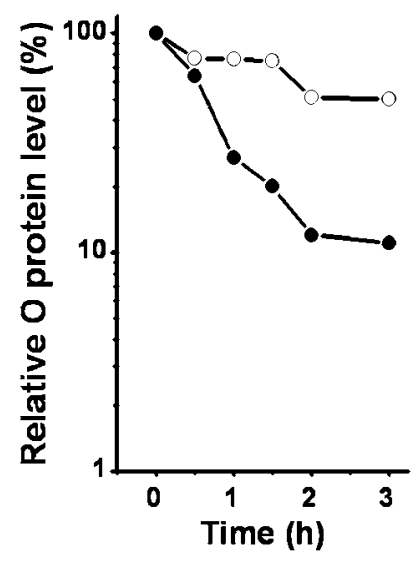

Fig. 4. Relative $O$ protein levels in $E$. coli seq $A^{+}(\bigcirc)$ and $\Delta$ seqA (๑) hosts bearing $\lambda$ plasmid (pKBlin). Bacterial cultures were pulse-labelled with $\left[{ }^{35} \mathrm{~S}\right]$ methionine and chased with an excess of non-radioactive methionine at time 0 . The $y$ axis shows the $O$ protein level as a percentage of that of the corresponding $E$. coli strain at time 0 .
$p_{\mathrm{R}}$ activity, but proceeds in relA (relaxed) mutants, unable to produce ppGpp in starved cells (Szalewska-Pałasz et al., 1994). Because of this, $\lambda$ plasmid replication in the amino acid-starved relA host reflects the efficiency of functioning of the heritable replication complex and the effectiveness of $p_{\mathrm{R}}$-initiated transcriptional activation of ori .

We found that in relA $\Delta$ seqA double-mutant cells growing exponentially in a minimal medium, the relative kinetics of replication of $\lambda$ plasmid DNA was at a level similar to that observed in the relA seqA ${ }^{+}$host [one should note a lower plasmid copy number in $\Delta$ seqA cells, as demonstrated previously (Słomińska et al., 2001) and confirmed in this report]. However, amino acid starvation caused an impairment in the plasmid DNA synthesis in the double (relA $\Delta$ seqA) mutant relative to the relA seqA ${ }^{+}$bacteria (Fig. 5). In contrast to the almost complete inhibition of $\lambda$ plasmid replication in the wild-type host (caused by accumulation of ppGpp and inhibition of transcription from $p_{\mathrm{R}}$ ), some increase in the amount of $\lambda$ DNA occurred in the relA $\Delta$ seq $A$ host during the relaxed response, but the efficiency of this process was significantly lower than that in the relA seqA ${ }^{+}$bacteria (Fig. 5).

\section{DISCUSSION}

Although the SeqA protein is one of major negative regulators of E. coli chromosome replication (see Introduction), little is known about the putative involvement of this

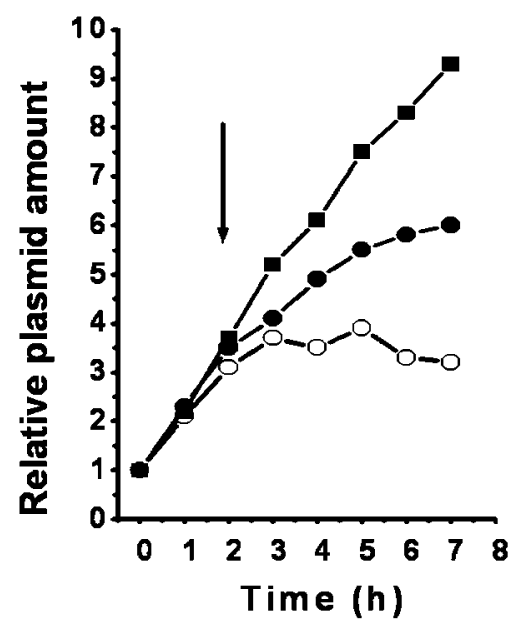

Fig. 5. Replication of $\lambda$ plasmid (pCB104) in amino acid-starved E. coli wild-type $\left(r e / A^{+} \operatorname{seq} A^{+}\right)$host $(\bigcirc)$, and $\Delta$ relA seq $A^{+}(\boldsymbol{\square})$ and $\triangle r e I A \Delta$ seqA $(\bullet)$ mutants. The results of experiments with the rel $A^{+} \Delta$ seqA strain were analogous to those obtained for rel $A^{+}$ seq $A^{+}$(data not shown). Isoleucine starvation was induced by the addition of L-valine up to $1 \mathrm{mg} \mathrm{ml}^{-1}$ at the time indicated by the arrow. The $y$ axis shows the amount of plasmid DNA relative to that of the corresponding $E$. coli strain at time 0 . 
factor in the control of the replication of other replicons. Examples of studies of the possible role of SeqA in the regulation of replication initiated from origins different from oriC include relatively preliminary observations only, namely the demonstration of the binding of this protein to bacteriophage P1 ori (Brendler et al., 1995), and the findings that the copy number of plasmids derived from bacteriophage $\lambda$ is decreased in a seqA mutant host (Słomińska et al., 2001) and that the $\Delta$ seqA mutation can suppress incompatibility between $\lambda$ plasmids and certain dnaA(ts) mutants (Słomińska et al., 2003b; Glinkowska et al., 2003). Here, we investigated the role of SeqA in the regulation of $\lambda$ DNA replication in more detail.

Since SeqA regulates replication from oriC directly (by binding specifically to the origin region, and influencing initiator protein function and changes in nucleoprotein structures in this region), which can be demonstrated in vitro (Slater et al., 1995; Wold et al., 1998; Torheim \& Skarstad, 1999), we asked whether the effect of this protein on $\lambda$ DNA replication is also direct. However, in contrast to a stimulation of $\lambda$ plasmid replication in vivo, deduced from the negative effects of the $\Delta s e q A$ mutation on plasmid copy number, a small negative effect of SeqA was observed in in vitro experiments (Fig. 1). Thus, in the absence of stimulation of $\lambda$ DNA replication by SeqA in vitro, we conclude that this protein controls the $\lambda$ replicon indirectly. One might argue that since SeqA interacts with cell membranes, which are missing in the in vitro replication assay, such an experimental system could be incomplete. Although we cannot exclude such a possibility, the fact that SeqA can clearly influence oriC-initiated replication in vitro (Wold et al., 1998; Torheim \& Skarstad, 1999), together with our results (this report), makes the putative hypothesis of a direct involvement of this protein in $\lambda$ DNA replication unlikely.

Despite the apparent lack of direct effects, there appears to be a significant role for SeqA in the regulation of $\lambda$ DNA replication. This can be concluded from the results of our density-shift experiments, which indicated considerable differences in the distribution of replication intermediates between wild-type and seqA hosts infected by bacteriophage $\lambda$ (Fig. 2). The movement of the parental radioactively labelled phage DNA toward the fully heavy position suggests that $\sigma$ replication intermediates appear earlier and are more abundant in the mutant, implying a role for SeqA in the switch from circle-to-circle to rollingcircle replication during bacteriophage development. The lack of the signal at the fully light position in the experiment with the seqA mutant (60 min after infection), in comparison with the wild-type host, is also intriguing. In theory, this could arise from the stimulation of either $\theta$ or $\sigma$ replication. However, since seq $A$ inactivation has a negative effect on the replication of $\lambda$ plasmids (Słomińska et al., 2001; see also Fig. 5 in this report), which replicate exclusively according to the $\theta$ mode, these results may support the hypothesis that SeqA delays the rolling-circle replication of phage $\lambda$ DNA.
Because it has been proposed previously that $\sigma$ replication of $\lambda$ DNA is preceded by one round of unidirectional $\theta$ replication (Barańska et al., 2001), the lack of a marked effect of the seqA mutation on the directionality of $\lambda$ plasmid replication (Fig. 3) might appear surprising. Nevertheless, this suggests that other processes and/or factors can also influence the mechanisms of the switch from an early to a late mode of DNA replication during bacteriophage $\lambda$ lytic development. One might be the stabilization of the $\lambda$ replication complex, which has in fact been postulated previously (Żylicz et al., 1998). The nucleoprotein complex formed at orid contains the $\mathrm{O}$ protein, which is protected from proteolysis by other components of this complex, and inherited by one of the two daughter copies of $\lambda$ DNA after each round of $\theta$ replication (Węgrzyn et al., 1992, 1996a; Węgrzyn \& Taylor, 1992; Potrykus et al., 2002). Since a free (unbound) form of the $O$ gene product is rapidly degraded in E. coli cells $\left(t_{1 / 2} \sim 1-2 \mathrm{~min}\right.$ ) (Węgrzyn et al., 1992), the efficiency of formation and persistence of the heritable replication complex may be deduced from the stability of the $\mathrm{O}$ protein in in vivo pulse-chase experiments. Interestingly, the stable fraction of the $\mathrm{O}$ protein was significantly less abundant in the seqA mutant relative to wild-type bacteria (Fig. 4), indicating an involvement of SeqA in either the formation of the stable $\lambda$ replication complex or its survival in cells. The mechanism of this phenomenon remains to be elucidated; nevertheless, it is worth noting that SeqA binds to a region of the $\lambda p_{\mathrm{R}}$ promoter and regulates its activity (Słomińska et al., 2001), and that a decrease in the abundance of the stable $\mathrm{O}$ protein fraction is also observed in cells bearing a derivative of $\lambda$ plasmid (pTC $\lambda 2)$ in which $p_{\mathrm{R}}$ is replaced by another promoter $\left(p_{\text {tet }}\right)$ (HermanAntosiewicz et al., 1998a) [the activity of the $p_{\text {tet }}$ promoter has been demonstrated to be SeqA independent (Słomińska et al., 2001)]. Moreover, another regulator of $p_{\mathrm{R}}$ activity, the DnaA protein (Szalewska-Pałasz et al., 1998; Glinkowska et al., 2003), has also been suggested to be a factor that influences the stability of the $\lambda$ replication complex (Herman-Antosiewicz et al., 1998a), and an interplay between DnaA and SeqA at the $p_{\mathrm{R}}$ promoter region has been clearly demonstrated (Słomińska et al., 2003b). In this light, seqA dysfunction-mediated suppression of the effects of certain $d n a A$ alleles on the transformation of $E$. coli cells with $\lambda$ plasmids, demonstrated previously (Glinkowska et al., 2001), and on the directionality of $\lambda$ plasmid replication, suggested in this report, may be important to understand the regulation of $\lambda$ DNA replication initiation. It is tempting to speculate that a nucleoprotein structure much larger than that suggested previously is formed at the $\lambda$ DNA region encompassing $p_{\mathrm{R}}$ and ori $\lambda$. SeqA and DnaA proteins might be involved in the formation of such a structure, which would control replication initiation from orid by both facilitating stabilization of the heritable replication complex and regulating $p_{\mathrm{R}}$-dependent transcriptional activation of the origin. A precedent for the formation of this kind of 'supercomplex' has already been described; namely, the ParB 
protein of phage $\mathrm{P} 1$ is capable of forming large complexes, due to spreading along DNA, which affect promoters located downstream (Rodionov \& Yarmolinsky, 2004). In this light, it is worth mentioning that the filamentous form of SeqA is able to induce negative DNA supercoiling (Odsbu et al., 2005). This might potentially affect both $p_{\mathrm{R}}$ activity and $\lambda \mathrm{O}$ protein stability.

The lack of drastic effects of SeqA on in vitro $\lambda$ DNA replication (Fig. 1), together with the moderate effect of $s e q A$ dysfunction on $\lambda$ plasmid and phage replication in vivo, suggests that this protein functions in the modulation of this process rather than being essential. However, such modulation can play an important regulatory role under different environmental and physiological conditions. Interestingly, bacteriophage $\lambda$ DNA replication based on an unstable, rather than stable, replication complex has been reported in UV-irradiated bacteria (Wegrzyn \& Węgrzyn, 2000), strengthening the hypothesis presented above.

If SeqA indeed modulates the efficiency of $\lambda$ DNA replication by regulating the stability of the replication complex and the transcriptional activation of ori $\lambda$, one should observe the most significant effects of seqA mutations on replication, which is totally dependent on these processes. Such replication occurs as the sole mode of $\lambda$ plasmid DNA synthesis during the relaxed response of bacterial cells to amino acid starvation (Taylor \& Węgrzyn, 1995; Szalewska-Palasz et al., 1994). Under these conditions, new $\lambda$ replication complexes cannot be formed due to the lack of amino acids, and the previously formed, heritable replication complex requires $p_{\mathrm{R}}$-initiated transcription to initiate DNA synthesis. In accordance with the above hypothesis, we observed a significant impairment of $\lambda$ plasmid replication in the amino acid-starved relA seq $A$ double mutant relative to the relA seqA ${ }^{+}$host (Fig. 5).

In conclusion, unlike the $E$. coli chromosome, the replication of which is negatively regulated by the sequestering of oriC due to binding of the SeqA protein to hemimethylated GATC motifs (Taghbalout et al., 2000; Guarne et al., 2005), replication of $\lambda$ DNA is moderately stimulated by SeqA rather than inhibited. This stimulation is indirect, brought about by stabilization of the heritable replication complex and stimulation of the transcriptional activation of ori $\lambda$, but may nevertheless play an important regulatory role, especially under various stress conditions. This also indicates that SeqA may differentially control the replication of various replicons, employing a large spectrum of molecular mechanisms. Such a function supports the proposal that this protein is a global regulator of processes occurring in bacterial cells. In fact, types of processes that have been demonstrated to be SeqA regulated in studies of bacteriophage $\lambda$, such as transcription regulation and the stabilization of protein complexes, may represent more general phenomena occurring in the host (E. coli) cells rather than being restricted solely to its parasite (phage $\lambda$ ).

\section{ACKNOWLEDGEMENTS}

We are grateful to Kirsten Skarstad for providing the seqA $\Delta 10$ mutant, SeqA protein and anti-SeqA antibodies, and to Roger McMacken, Johns Hopkins University, and Igor Konieczny and Krzysztof Liberek, University of Gdańsk, for discussions and for providing samples of proteins at early stages of this study. The assistance of Ewa Wójtowicz and Jacek Trzeszczyński in the construction of plasmid pEW1 and electron-microscopic studies, respectively, is acknowledged. This work was supported by the Polish Ministry of Science and Higher Education (project grant no. N301 122 31/3747)

\section{REFERENCES}

Appleyard, R. K. (1954). Segregation of new lysogenic types during growth of a doubly lysogenic strain derived from Escherichia coli K12. Genetics 39, 440-452.

Bach, T., Krekling, M. A. \& Skarstad, K. (2003). Excess SeqA prolongs sequestration of oriC and delays nucleoid segregation and cell division. EMBO J 22, 315-323.

Barańska, S., Gabig, M., Węgrzyn, A., Konopa, G., HermanAntosiewicz, A., Hernandez, P., Schvartzman, J. B., Helinski, D. R. \& Węgrzyn, G. (2001). Regulation of the switch from early to late bacteriophage $\lambda$ DNA replication mode. Microbiology 147, 535-547.

Boyd, A. C. \& Sherratt, D. J. (1995). The pCLIP plasmids: versatile cloning vectors based on the bacteriophage $\lambda$ origin of replication. Gene 153, 57-62.

Boye, E., Stokke, T., Kleckner, N. \& Skarstad, K. (1996). Coordinating DNA replication initiation with cell growth: differential roles for DnaA and SeqA proteins. Proc Natl Acad Sci U S A 93, 12206-12211.

Brendler, T. \& Austin, S. (1999). Binding of SeqA protein to DNA requires interaction between two or more complexes bound to separate hemimethylated GATC sequences. EMBO J 18, 2304-2310.

Brendler, T., Abeles, A. \& Austin, S. (1995). A protein that binds to the $\mathrm{P} 1$ origin core and the oriC 13 mer region in a methylationspecific fashion is the product of the host seqA gene. EMBO J 14, 4083-4090.

Burkardt, H. \& Lurz, R. (1984). Electron microscopy. In Advanced Molecular Genetics, pp. 281-313. Edited by A. Puhler \& K. N. Timmis. Berlin, Heidelberg: Springer Verlag.

Duncker, B. P., Shimada, K., Tsai-Pflugfelder, M., Pasero, P. \& Gasser, S. M. (2002). An N-terminal domain of Dbf4p mediates interaction with both origin recognition complex (ORC) and Rad53p and can deregulate late origin firing. Proc Natl Acad Sci U S A 99, 16087-16092.

Fossum, S., Soreide, S. \& Skarstad, K. (2003). Lack of SeqA focus formation, specific DNA binding and proper protein multimerization in the Escherichia coli sequestration mutant seqA2. Mol Microbiol 47, 619-632.

Fujikawa, N., Kurumizaka, H., Yamazoe, M., Hiraga, S. \& Yokoyama, S. (2003). Identification of functional domains of the Escherichia coli SeqA protein. Biochem Biophys Res Commun 300, 699-705.

Fujikawa, N., Kurumizaka, H., Nureki, O., Tanaka, Y., Yamazoe, M., Hiraga, S. \& Yokoyama, S. (2004). Structural and biochemical analyses of hemimethylated DNA binding by the SeqA protein. Nucleic Acids Res 32, 82-92.

Fuller, R. S., Kaguni, J. M. \& Kornberg, A. (1981). Enzymatic replication of the origin of the Escherichia coli chromosome. Proc Natl Acad Sci U S A 78, 7370-7374. 
Glinkowska, M., Konopa, G., Węgrzyn, A., Herman-Antosiewicz, A., Weigel, C., Seitz, H., Messer, W. \& Węgrzyn, G. (2001). The double mechanism of incompatibility between $\lambda$ plasmids and Escherichia coli dnaA(ts) host cells. Microbiology 147, 1923-1928.

Glinkowska, M., Majka, J., Messer, W. \& Węgrzyn, G. (2003). The mechanism of regulation of bacteriophage $\lambda p_{\mathrm{R}}$ promoter activity by Escherichia coli DnaA protein. J Biol Chem 278, 22250-22256.

Goldberg, A. R. \& Howe, M. (1969). New mutations in the $S$ cistron of bacteriophage $\lambda$ affecting host cell lysis. Virology 38, 200-202.

Guarne, A., Zhao, Q., Ghirlando, R. \& Yang, W. (2002). Insights into negative modulation of $E$. coli replication initiation from the structure of SeqA-hemimethylated DNA complex. Nat Struct Biol 9, 839-843.

Guarne, A., Brendler, T., Zhao, Q., Ghirlando, R., Austin, S. \& Yang, W. (2005). Crystal structure of a SeqA-N filament: implications for DNA replication and chromosome organization. EMBO J 24, 1502-1511.

Han, J. S., Kang, S., Lee, H., Kim, H. K. \& Hwang, D. S. (2003). Sequential binding of SeqA to paired hemi-methylated GATC sequences mediates formation of higher order complexes. $J$ Biol Chem 278, 34983-34989.

Han, J. S., Kang, S., Kim, S. H., Ko, M. J. \& Hwang, D. S. (2004). Binding of SeqA protein to hemi-methylated GATC sequences enhances their interaction and aggregation properties. J Biol Chem 279, 30236-30243.

Hardy, C. D. \& Cozzarelli, N. R. (2005). A genetic selection for supercoiling mutants of Escherichia coli reveals proteins implicated in chromosome structure. Mol Microbiol 57, 1636-1652.

Herman-Antosiewicz, A., Węgrzyn, A., Taylor, K. \& Węgrzyn, G. (1998a). DnaA-mediated regulation of phage $\lambda$-derived replicons in the absence of $p_{\mathrm{R}}$ and Cro function. Virology 249, 98-107.

Herman-Antosiewicz, A., Śrutkowska, S., Taylor, K. \& Węgrzyn, G. (1998b). Replication and maintenance of $\lambda$ plasmids devoid of the Cro repressor autoregulatory loop in Escherichia coli. Plasmid 40, 113-125.

Hiraga, S., Ichinose, C., Niki, H. \& Yamazoe, M. (1998). Cell cycledependent duplication and bidirectional migration of SeqA-associated DNA-protein complexes in E. coli. Mol Cell 1, 381-387.

Jensen, K. F. (1993). The Escherichia coli 'wild types' W3110 and MG1655 have an $r p h$ frameshift mutation that leads to pyrimidine starvation due to low pyrE expression levels. J Bacteriol 175, 34013407.

Kang, S., Lee, H., Han, J. S. \& Hwang, D. S. (1999). Interaction of SeqA and Dam methylase on the hemimethylated origin of Escherichia coli chromosomal DNA replication. J Biol Chem 274, 11463-11468.

Klungsoyr, H. K. \& Skarstad, K. (2004). Positive supercoiling is generated in the presence of Escherichia coli SeqA protein. Mol Microbiol 54, 123-131.

Konieczny, I. \& Marszałek, J. (1995). The requirement for molecular chaperones in $\lambda$ DNA replication is reduced by the mutation $\pi$ in $\lambda P$ gene, which weakens the interaction between $\lambda \mathrm{P}$ protein and DnaB helicase. J Biol Chem 270, 9792-9799.

Kornberg, A. \& Baker, T. A. (1992). DNA Replication. New York: W. H. Freeman.

Kur, J., Gorska, I. \& Taylor, K. (1987). Escherichia coli dnaA initiation function is required for replication of plasmids derived from coliphage lambda. J Mol Biol 198, 203-210.

Lee, H., Kang, S., Bae, S. H., Choi, B. S. \& Hwang, D. S. (2001). SeqA protein aggregation is necessary for SeqA function. J Biol Chem 276, 34600-34606.

Li, C. J. \& DePamphilis, M. L. (2002). Mammalian Orcl protein is selectively released from chromatin and ubiquitinated during the $S$ to-M transition in the cell division cycle. Mol Cell Biol 22, 105-116.
Lobner-Olesen, A., Marinus, M. G. \& Hansen, F. G. (2003). Role of SeqA and Dam in Escherichia coli gene expression: a global/microarray analysis. Proc Natl Acad Sci U S A 100, 4672-4677.

Lu, M., Campbell, J. L., Boye, E. \& Kleckner, N. (1994). SeqA: a negative modulator of replication initiation in E. coli. Cell 77, 413426.

Messer, W. (2002). The bacterial initiator DnaA. DnaA and oriC, the bacterial mode to initiate DNA replication. FEMS Microbiol Rev 26, 355-374.

Odsbu, I., Klungsoyr, H. K., Fossum, S. \& Skarstad, K. (2005). Specific N-terminal interactions of the Escherichia coli SeqA protein are required to form multimers that restrain negative supercoils and form foci. Genes Cells 10, 1039-1049.

Polissi, A., Goffin, L. \& Georgopoulos, C. (1995). The Escherichia coli heat shock response and bacteriophage lambda development. FEMS Microbiol Rev 17, 159-169.

Potrykus, K., Barańska, S., Węgrzyn, A. \& Węgrzyn, G. (2002). Composition of the $\lambda$ plasmid heritable replication complex. Biochem J 364, 857-862.

Rodionov, O. \& Yarmolinsky, M. (2004). Plasmid partitioning and the spreading of P1 partition protein ParB. Mol Microbiol 52, 1215-1223.

Sambrook, J., Fritsch, E. F. \& Maniatis, T. (1989). Molecular Cloning: a Laboratory Manual, 2nd edn. Cold Spring Harbor, NY: Cold Spring Harbor Laboratory.

Skarstad, K., Lueder, G., Lurz, R., Speck, C. \& Messer, W. (2000). The Escherichia coli SeqA protein binds specifically and cooperatively to two sites in hemimethylated and fully methylated oriC. Mol Microbiol 36, 1319-1326.

Skarstad, K., Torheim, N., Wold, S., Lurz, R., Messer, W., Fossum, S. \& Bach, T. (2001). The Escherichia coli SeqA protein binds specifically to two sites in fully and hemimethylated oriC and has the capacity to inhibit DNA replication and affect chromosome topology. Biochimie 83, 49-51.

Slater, S., Wold, S., Lu, M., Boye, E., Skarstad, K. \& Kleckner, N. (1995). E. coli SeqA protein binds oriC in two different methylmodulated reactions appropriate to its roles in DNA replication initiation and origin sequestration. Cell 82, 927-936.

Słomińska, M., Węgrzyn, A., Konopa, G., Skarstad, K. \& Węgrzyn, G. (2001). SeqA, the Escherichia coli origin sequestration protein, is also a specific transcription factor. Mol Microbiol 40, 1371-1379.

Słomińska, M., Konopa, G., Ostrowska, J., Kędzierska, B., Węgrzyn, G. \& Węgrzyn, A. (2003a). SeqA-mediated stimulation of a promoter activity by facilitating functions of a transcription activator. $\mathrm{Mol}$ Microbiol 47, 1669-1679.

Słomińska, M., Konopa, G., Barańska, S., Węgrzyn, G. \& Węgrzyn, A. (2003b). Interplay between DnaA and SeqA proteins during regulation of bacteriophage $\lambda p_{\mathrm{R}}$ promoter activity. J Mol Biol 329, 59-68.

Słomińska, M., Wahl, A., Węgrzyn, G. \& Skarstad, K. (2003c). The degradation of mutant initiator protein DnaA204 by proteases ClpP, ClpQ and Lon is prevented when DNA is SeqA-free. Biochem J 370, 867-871.

Śrutkowska, S., Konopa, G. \& Węgrzyn, G. (1998). A method for isolation of plasmid DNA replication intermediates from unsynchronized bacterial cultures for electron microscopy analysis. Acta Biochim Pol 45, 233-240.

Śrutkowska, S., Caspi, R., Gabig, M. \& Węgrzyn, G. (1999). Detection of DNA replication intermediates after two-dimensional agarose gel electrophoresis using a fluorescein-labeled probe. Anal Biochem 269, 221-222. 
Szalewska-Pałasz, A., Węgrzyn, A., Herman, A. \& Węgrzyn, G. (1994). The mechanism of the stringent control of $\lambda$ plasmid DNA replication. EMBO J 13, 5779-5785.

Szalewska-Pałasz, A., Węgrzyn, A., Błaszczak, A., Taylor, K. \& Węgrzyn, G. (1998). DnaA-stimulated transcriptional activation of ori $\lambda$ : Escherichia coli RNA polymerase $\beta$ subunit as a transcriptional activator contact site. Proc Natl Acad Sci U S A 95, 4241-4246.

Tabor, S. \& Richardson, C. C. (1985). A bacteriophage T7 RNA polymerase/promoter system for controlled exclusive expression of specific genes. Proc Natl Acad Sci U S A 82, 1074-1078.

Taghbalout, A., Landoulsi, A., Kern, R., Yamazoe, M., Hiraga, S., Holland, B., Kohiyama, M. \& Malki, A. (2000). Competition between the replication initiator DnaA and the sequestration factor SeqA for binding to the hemimethylated chromosomal origin of $E$. coli in vitro. Genes Cells 5, 873-884.

Taylor, K. \& Węgrzyn, G. (1995). Replication of coliphage lambda DNA. FEMS Microbiol Rev 17, 109-119.

Torheim, N. K. \& Skarstad, K. (1999). Escherichia coli SeqA protein affects DNA topology and inhibits open complex formation at oriC. EMBO J 18, 4882-4888.

Torheim, N. K., Boye, E., Lobner-Olesen, A., Stokke, T. \& Skarstad, K. (2000). The Escherichia coli SeqA protein destabilizes mutant DnaA204 protein. Mol Microbiol 37, 629-638.

Viguera, E., Hernandez, P., Krimer, D. B., Boistov, A. S., Lurz, R., Alonso, J. C. \& Schvartzman, J. B. (1996). The ColE1 unidirectional origin acts as a polar replication fork pausing site. J Biol Chem 271, 22414-22421.

Viguera, E., Rodríguez, A., Krimer, D. B., Hernández, P., Trelles, O. \& Schvartzman, J. B. (1998). A computer model for the analysis of DNA replication intermediates by two-dimensional (2D) agarose gel electrophoresis. Gene 217, 41-49.

Vinga, I., Sao-Jose, C., Tavares, P. \& Santos, M. A. (2006). Bacteriophage entry in the host cell. In Modern Bacteriophage Biology and Biotechnology, pp. 163-203. Edited by G. Węgrzyn. Kerala: Research Signpost.

von Freiesleben, U., Rasmussen, K. V. \& Schaechter, M. (1994). SeqA limits DnaA activity in replication from oriC in Escherichia coli. Mol Microbiol 14, 763-772.

Węgrzyn, A. (2006). DnaA and SeqA proteins of Escherichia coli as regulators of bacteriophage $\lambda$ development. In Modern Bacteriophage Biology and Biotechnology, pp. 79-101. Edited by G. Węgrzyn. Kerala: Research Signpost.

Węgrzyn, G. \& Taylor, K. (1992). Inheritance of the replication complex by one of two daughter copies during $\lambda$ plasmid replication in Escherichia coli. J Mol Biol 226, 681-688.

Węgrzyn, A. \& Węgrzyn, G. (2000). Formation and stability of bacteriophage $\lambda$ replication complexes in UV-irradiated Escherichia coli. Curr Microbiol 41, 157-160.

Węgrzyn, G. \& Węgrzyn, A. (2002). Regulation of bacteriophage $\lambda$ DNA replication. Curr Top Virol 2, 187-194.
Węgrzyn, G. \& Węgrzyn, A. (2005). Genetic switches during bacteriophage lambda development. Prog Nucleic Acid Res Mol Biol 79, 1-48.

Węgrzyn, G., Pawłowicz, A. \& Taylor, K. (1992). Stability of coliphage $\lambda$ DNA replication initiator, the $\lambda \mathrm{O}$ protein. J Mol Biol 226, 675-680.

Węgrzyn, A., Węgrzyn, G. \& Taylor, K. (1995a). Protection of coliphage $\lambda \mathrm{O}$ initiator protein from proteolysis in the assembly of the replication complex in vivo. Virology 207, 179-184.

Węgrzyn, G., Węgrzyn, A., Konieczny, I., Bielawski, K., Konopa, G., Obuchowski, M., Helinski, D. R. \& Taylor, K. (1995b). Involvement of the host initiator function $d n a A$ in the replication of coliphage $\lambda$. Genetics 139, 1469-1481.

Węgrzyn, A., Węgrzyn, G., Herman, A. \& Taylor, K. (1996a). Protein inheritance: $\lambda$ plasmid replication perpetuated by the heritable replication complex. Genes Cells 1, 953-963.

Węgrzyn, A., Węgrzyn, G. \& Taylor, K. (1996b). Disassembly of the coliphage $\lambda$ replication complex due to heat shock induction of the groE operon. Virology 217, 594-597.

Węgrzyn, A., Herman-Antosiewicz, A., Taylor, K. \& Węgrzyn, G. (1998). Molecular mechanism of heat shock-provoked disassembly of the coliphage $\lambda$ replication complex. J Bacteriol 180, 2475-2483.

Węgrzyn, A., Wróbel, B. \& Węgrzyn, G. (1999). Altered biological properties of cell membranes in Escherichia coli dnaA and seqA mutants. Mol Gen Genet 261, 762-769.

Weitao, T., Nordstrom, K. \& Dasgupta, S. (1999). Mutual suppression of $m u k B$ and $s e q A$ phenotypes might arise from their opposing influences on the Escherichia coli nucleoid structure. Mol Microbiol 34, 157-168.

Wold, M. S., Mallory, J. B., Roberts, J. D., LeBowitz, J. H. \& McMacken, R. (1982). Initiation of bacteriophage $\lambda$ DNA replication in vitro with purified $\lambda$ replication proteins. Proc Natl Acad Sci U S A 79, 61766180.

Wold, S., Boye, E., Slater, S., Kleckner, N. \& Skarstad, K. (1998). Effects of purified SeqA protein on oriC-dependent DNA replication in vitro. EMBO J 17, 4158-4165.

Xiao, H., Kalman, M., Ikehara, K., Zemel, S., Glaser, G. \& Cashel, M. (1991). Residual guanosine $3^{\prime}, 5^{\prime}$-bispyrophosphate synthetic activity of relA null mutants can be eliminated by spoT null mutations. J Biol Chem 266, 5980-5990.

Żylicz, M., Gorska, I., Taylor, K. \& Georgopoulos, C. (1984). Bacteriophage $\lambda$ replication proteins: formation of a mixed oligomer and binding to the origin of $\lambda$ DNA. Mol Gen Genet 196, 401-406.

Żylicz, M., Liberek, K., Wawrzynów, A. \& Georgopoulos, C. (1998). Formation of the preprimosome protects $\lambda \mathrm{O}$ from RNA transcription-dependent proteolysis by ClpP/ClpX. Proc Natl Acad Sci U S A 95, 15259-15263.

Edited by: L. Jannière 